\title{
Sonia Faessel et Frédéric Angleviel, Si Nouméa m'était contée... Anthologie
}

2000, Groupe de recherche en histoire océanienne contemporaine, Université de Nouvelle-Calédonie, Nouméa, Publication du GRHOC $n^{\circ} 1$, $140 \mathrm{p}$.

Isabelle Leblic

\section{(2) OpenEdition}

\section{Journals}

Édition électronique

URL : http://journals.openedition.org/jso/1236

DOI : $10.4000 /$ jso. 1236

ISSN : $1760-7256$

Éditeur

Société des océanistes

\section{Édition imprimée}

Date de publication : 1 juin 2003

Pagination : 117-118

ISSN : 0300-953x

\section{Référence électronique}

Isabelle Leblic, «Sonia Faessel et Frédéric Angleviel, Si Nouméa m'était contée... Anthologie », Journal de la Société des Océanistes [En ligne], 116 | Année 2003-1, mis en ligne le 26 mai 2008, consulté le 24 septembre 2020. URL : http://journals.openedition.org/jso/1236 ; DOI : https://doi.org/10.4000/jso. 1236

Ce document a été généré automatiquement le 24 septembre 2020.

(c) Tous droits réservés 


\section{Sonia Faessel et Frédéric Angleviel, Si Nouméa m'était contée... Anthologie}

2000, Groupe de recherche en histoire océanienne contemporaine, Université de Nouvelle-Calédonie, Nouméa, Publication du GRHOC $n^{\circ} 1$, $140 \mathrm{p}$.

Isabelle Leblic

\section{RÉFÉRENCE}

Sonia Faessel et Frédéric Angleviel, Si Nouméa m'était contée... Anthologie, 2000, Groupe de recherche en histoire océanienne contemporaine, Université de Nouvelle-Calédonie, Nouméa, Publication du GRHOC n 1,140 p.

INDEX

Index géographique : Nouméa, Nouvelle-Calédonie

\section{AUTEURS}

ISABELLE LEBLIC

LACITO-CNRS 